\title{
Metan z pokładów węgla (CBM) - doświadczenia światowe i perspektywy rozwoju w Polsce
}

\begin{abstract}
W artykule przedstawiono rozmieszczenie i wartości udokumentowanych zasobów geologicznych metanu w pokładach węgla (CBM) na świecie oraz dane dotyczące ich wydobycia. Scharakteryzowano warunki występowania akumulacji metanu w pokładach węgla kamiennego. Omówiono korzyści płynące z wykorzystania metanu w procesach technologiczno-produkcyjnych oraz zagrożenia związane z jego wydobyciem.
\end{abstract}

Słowa kluczowe: metan z pokładów węgla, zasoby i produkcja CBM, emisja gazów cieplarnianych, gaz adsorbowany, sekwestracja, desorpcja.

\section{Coalbed methane (CBM) - global experience and the prospects of development in Poland}

The paper presents the distribution and value of documented coalbed methane (CBM) geological resources in the world and presents the history of the production of coaldbed gas. Conditions of the CBM accumulations occurrence were characterized. The benefits of using methane in the process of technological production - and the risks associated with its extraction were discussed.

Key words: coalbed methane (CBM), CBM geological resources, greenhouse gas emissions, gas adsorbed, sequestration, desorption.

\section{Wprowadzenie}

Stały globalny rozwój gospodarczy i cywilizacyjny wymusza zwiększenie zużycia energii, czego konsekwencją jest ciągły wzrost zapotrzebowania na nią. Podstawowym jej źródłem są paliwa kopalne (głównie węgiel), których wykorzystywanie powoduje emisję do atmosfery wielu szkodliwych dla środowiska naturalnego związków chemicznych, w tym gazów cieplarnianych (głównie $\mathrm{CO}_{2}$ ), powodujących globalne ocieplenie klimatu. Międzynarodowe umowy zawarte w ramach globalnych porozumień klimatycznych zobowiązują poszczególne kraje do ograniczenia emisji gazów cieplarnianych, a zwłaszcza $\mathrm{CO}_{2}$, co powoduje wzrost zapotrzebowania na źródła „,czystej energii”. Metan jest głównym składnikiem akumulacji gazu ziemnego typu CBM (coalbed methane) w pokładach węgla kamiennego oraz akumulacji typu tight gas (gazu zamkniętego) w formacjach mułowcowo-piaszczystych, obecnych pomiędzy pokładami węgla kamiennego. Polska posiada jedne z największych w Europie złoża węgla kamiennego, którym towarzyszy występowanie metanu. Jednostkowa zawartość metanu w pokładach węgla dochodzi do kilkunastu metrów sześciennych na tonę węgla $\left(\mathrm{m}^{3} \mathrm{CH}_{4} / \mathrm{t}\right)$, co w skali całego basenu niecki Górnośląskiego Zagłębia Węglowego (GZW) daje biliony metrów sześciennych gazu. Być może opracowanie technologii rentownego pozyskiwania metanu z pokładów węgla kamiennego niecki GZW stanowiłoby optymistyczną alternatywę wobec mglistych perspektyw odkryć niekonwencjonalnych złóż węglowodorów w paleozoicznych formacjach łupkowych północnej i wschodniej Polski.

Metan jest spośród kopalnych surowców energetycznych najczystszym źródłem energii. Charakteryzuje się najniższym współczynnikiem emisyjności $\mathrm{CO}_{2}$, prawie dwa razy mniejszym niż w przypadku węgla.

Zwiększenie udziału metanu (kosztem węgla) w produkcji energii ( $w$ bilansie energetycznym kraju) bezpośrednio wpłynęłoby na redukcję emisji $\mathrm{CO}_{2}$. Działania w tym kierunku pomogłyby w dotrzymaniu zobowiązań wynikających z kwot 
emisyjnych narzuconych w ramach międzynarodowych porozumień klimatycznych, co w efekcie mogłoby przełożyć się również na długofalowe korzyści finansowe dla kraju. Wykorzystanie metanu z pokładów węgla niecki GZW ograniczyłoby również zużycie węgla, a tym samym przedostawanie się do środowiska naturalnego niezwykle szkodliwych związków siarki, azotu, metali ciężkich itp. W tym kontekście przemysłowe zagospodarowanie metanu z pokładów węgla wpisuje się w działania na rzecz ochrony środowiska naturalnego oraz zapobiegania globalnemu ocieplaniu klimatu naszej planety.

\section{Światowe zasoby i produkcja metanu w pokładach węgla}

Akumulacje metanu w pokładach węgla kamiennego (CBM) udokumentowane są na wszystkich kontynentach (rysunek 1). Jego światowe zasoby geologiczne szacowane są przez Advanced Resources International (ARI) [5] na $100 \div 216$ bln m$^{3}$, z czego około 24 bln $^{3}$ ocenia sie na wydobywalne [8]. Inni autorzy $[15,20]$ podają, że wartości zasobów geologicznych CBM wynoszą od 113 bln $\mathrm{m}^{3}$ do 184 bln $\mathrm{m}^{3}$, przy czym zasoby wydobywalne to około $42 \mathrm{bln}^{3}$. Mając na uwadze różne źródła danych $[1,5,8]$, można stwierdzić, że światowymi liderami z punktu widzenia zasobów geologicznych CBM są Rosja, USA, Chiny, Australia i Kanada (tablica 1).

Precyzyjne i jednoznaczne ustalenie zasobów metanu w pokładach węgla oraz wielkości jego wydobycia w skali globalnej jest trudne do zrealizowania z kilku powodów, wśród których wyróżnia się: różnorodność terminologiczną, różnice metod szacowania zasobów, wielość podmiotów publikujących dane statystyczne, a także niedostateczne rozpoznanie w skali poszczególnych krajów [13].
Złoża CBM są objęte zasadniczo tymi samymi procedurami związanymi z poszukiwaniem, wydobyciem i dokumentowaniem co konwencjonalne złoża węglowodorów. Jednak metody szacowania zasobów metanu z pokładów węgla powinny uwzględniać główne różnice między nimi (tablica 2), ponieważ przekłada się to na zmienność parametrów złożowych wykorzystywanych do estymacji ilości CBM w danym basenie [5].

Historia wydobycia metanu z pokładów węgla na świecie rozpoczęła się w Stanach Zjednoczonych w latach 70 . XX wieku. Rządowa agencja do spraw kopalin U.S. Bureau of Mines wdrożyła odmetanowywanie pokładów węgla, przed ich eksploatacją, poprzez otwory z powierzchni. Komercyjną produkcję metanu $\mathrm{z}$ tego typu złóż uruchomiono pod koniec lat 80 . Sprzyjały jej ulgi podatkowe wprowadzone przez rząd USA dla producentów gazu ze złóż niekonwencjonalnych [5], nowe technologie oraz rozszerzenie poszukiwań w obszarze nowych basenów [6]. Od tego czasu wydobycie gazu systematycznie rosło, osiągając najwyższy

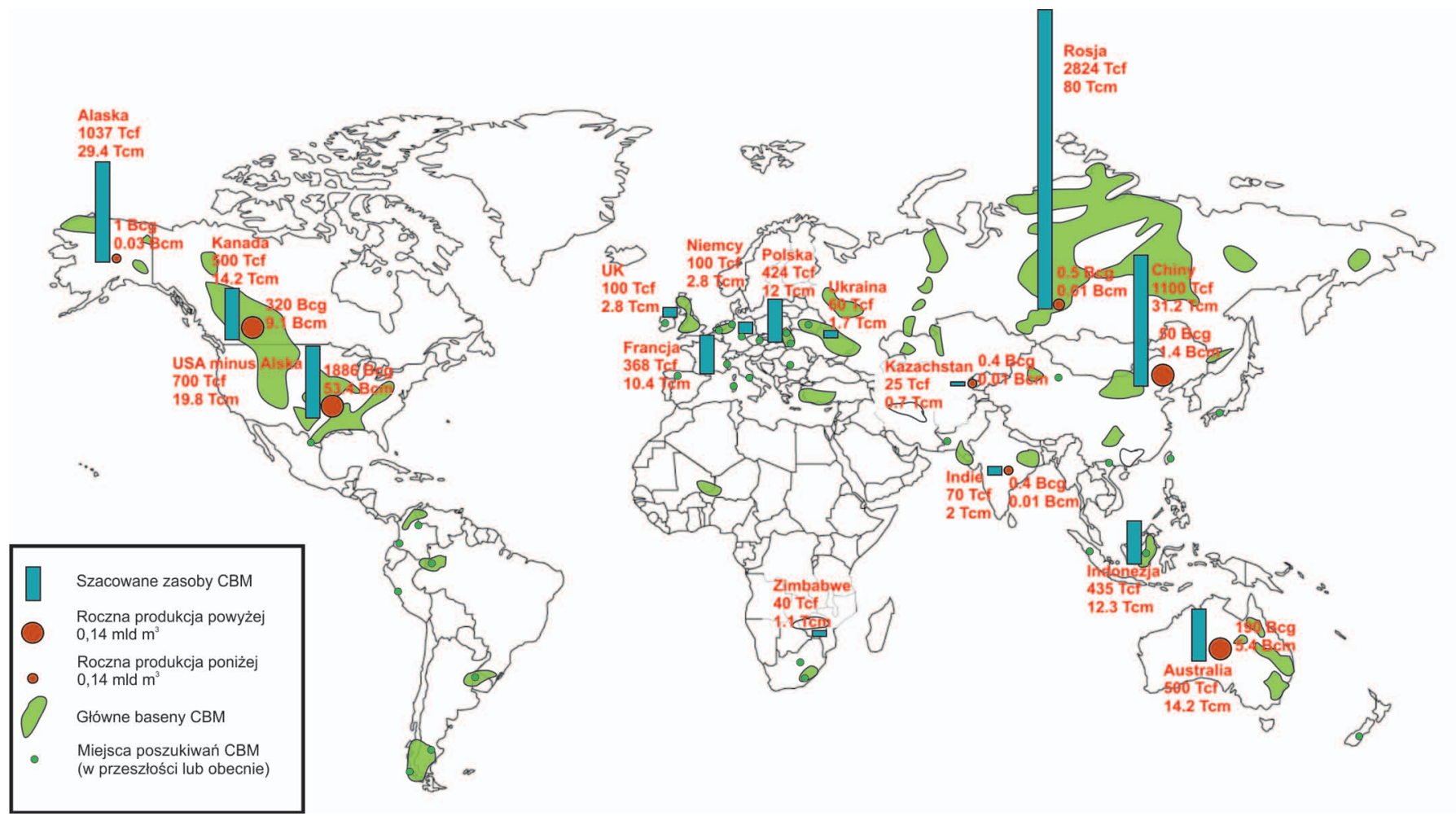

Rys. 1. Mapa rozmieszczenia zasobów metanu w pokładach węgla kamiennego (CBM) na świecie

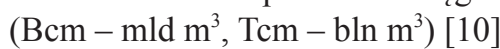


Tablica 1. Szacowane zasoby geologiczne oraz wydobywalne metanu z pokładów węgla na świecie [8, 19]

\begin{tabular}{|c|c|c|c|c|c|c|}
\hline \multirow{2}{*}{ Kraj } & \multicolumn{2}{|c|}{ Zasoby geologiczne według [8] } & \multicolumn{2}{|c|}{ Zasoby wydobywalne według [8] } & \multicolumn{2}{|c|}{ Zasoby geologiczne według [10] } \\
\hline & {$[\mathrm{Tcf}]$} & {$\left[\mathrm{bln} \mathrm{m}^{3}\right]$} & [Tcf] & {$\left[\mathrm{bln} \mathrm{m}^{3}\right]$} & {$[\mathrm{Tcf}]$} & {$\left[\mathrm{bln} \mathrm{m}^{3}\right]$} \\
\hline Rosja & $450 \div 2000$ & $12,7 \div 56,6$ & 200 & 5,66 & 2842 & 80,0 \\
\hline Chiny & $700 \div 1270$ & $19,8 \div 35,9$ & 100 & 2,83 & 1100 & 31,2 \\
\hline Stany Zjednoczone & $500 \div 1500$ & $14,2 \div 42,5$ & 140 & 3,96 & 1737 & 49,2 \\
\hline Australia & $500 \div 1000$ & $14,2 \div 28,3$ & 120 & 3,40 & 500 & 14,2 \\
\hline Kanada & $360 \div 460$ & $10,2 \div 13,0$ & 90 & 2,55 & 500 & 14,2 \\
\hline Indonezja & $340 \div 450$ & $9,6 \div 12,7$ & 50 & 1,42 & 435 & 12,3 \\
\hline Południowa Afryka & $90 \div 220$ & $2,5 \div 6,2$ & 30 & 0,85 & bd & bd \\
\hline Europa Zachodnia & 200 & 5,7 & 20 & 0,57 & 568 & 16,0 \\
\hline Ukraina & 170 & 4,8 & 25 & 0,71 & 60 & 1,7 \\
\hline Turcja & $50 \div 110$ & $1,4 \div 3,1$ & 10 & 0,28 & bd & bd \\
\hline Indie & $70 \div 90$ & $2,0 \div 2,5$ & 20 & 0,57 & 70 & 2 \\
\hline Kazachstan & $40 \div 60$ & $1,1 \div 1,7$ & 10 & 0,28 & 25 & 0,7 \\
\hline Ameryka Południowa & 50 & 1,4 & 10 & 0,28 & bd & bd \\
\hline Polska & $20 \div 50$ & $0,6 \div 1,4$ & 5 & 0,14 & 424 & 12,0 \\
\hline Suma & $3540 \div 7630$ & $100,2 \div 215,8$ & 830 & 23,5 & 8261 & 233,5 \\
\hline
\end{tabular}

poziom $56 \mathrm{mld} \mathrm{m}^{3}(10 \%$ całkowitego wydobycia tego surowca) w $2008 \mathrm{r}$. (rysunek 2), dając Stanom Zjednoczonym pozycję światowego lidera w produkcji CBM [1]. Od 2009 r. wydobycie stale maleje, co związane jest z brakiem aktywności poszukiwawczej, który wynika z takich czynników jak: niskie szanse na odkrycie nowych złóż, niskie ceny gazu oraz skupienie się sektora wydobywczego na gazie z formacji łupkowych [5].

Kolejnymi krajami liczącymi się w pozyskiwaniu (na podobnym poziomie) metanu pokładów węgla, choć nie na tak dużą skalę jak USA, są Kanada oraz Australia.

W Kanadzie głównym regionem ze złożami tego typu jest prowincja Alberta. Pierwsze próby wydobycia podjęto tam, podobnie jak w USA, w latach 70. ubiegłego stulecia, jednak produkcja na komercyjną skalę miała swój początek w 2002 r. Jej poziom regularnie wzrastał, osiagając wartości: 2,5 mld m ${ }^{3}$ w 2005 r., 5,2 mld m w 2008 r., 7,2 $\mathrm{mld} \mathrm{m}^{3}$ w 2010 r., a w 2015 r. wydobycie 14,5 mld $\mathrm{m}^{3}$ dało Kanadzie drugą pozycję w rankingu producentów CBM na świecie [17].

Trzecim producentem CBM jest Australia, gdzie w 2015 r. wydobyto $12,3 \mathrm{mld} \mathrm{m}^{3}$ gazu (rysunek 3) [4]. Pierwsza przemysłowa produkcja została uzyskana w 1996 r. w zagłębiu Bowen. Do dziś zagłębie to oraz zagłębie Surat są głównymi obszarami źródłowymi (95\%) metanu w Australii [20].
Dynamiczny wzrost wydobycia w ciągu ostatnich 8 lat związany jest z produkcją gazu skroplonego LNG w celach eksportowych [5].

Pozostałymi krajami produkującymi CBM są Chiny i Indie, w których wydobycie rozwinęło się w ostatnich $10 \div 15$ latach i wyniosło w 2015 r. - 4,4 mld $\mathrm{m}^{3} \mathrm{w}$ Chinach [9] i około $360 \mathrm{mln} \mathrm{m}^{3} \mathrm{w}$ Indiach (dane szacunkowe) [16].

W pozostałych krajach (tablica 1), mimo posiadanych przez nie zasobów, nie odnotowuje się przemysłowej produkcji metanu z nienaruszonych pokładów węgla. Spośród nich na szczególną uwagę zasługuje Rosja, której zasoby CBM (do $80 \mathrm{bln}^{3}$ ) stanowią 30\% całości prognozowanych zasobów metanu, a warunki geologiczne i wydobywcze są zbli- 
żone do tych, jakie występują u wiodących producentów gazu z pokładów węgla, czyli USA, Kanady i Australii. Głównymi utrudnieniami stojącymi na przeszkodzie w rozwoju tej gałęzi wydobywczej jest duża konkurencja złóż konwencjonalnych o niskim koszcie produkcji oraz utrzymywanie się niskiej ceny tego surowca [12].

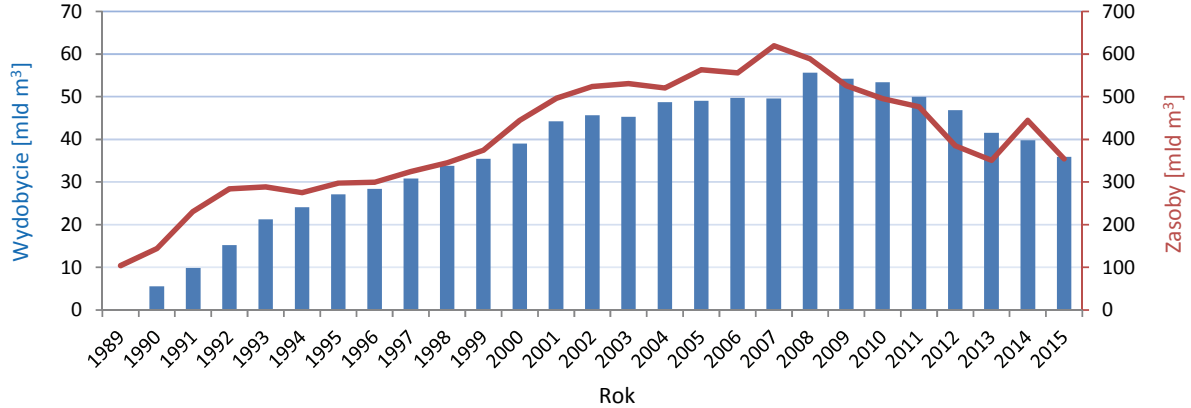

Rys. 2. Wydobycie oraz zasoby eksploatacyjne metanu z pokładów węgla w Stanach Zjednoczonych w latach 1989-2015 [18, 19, poprawione]

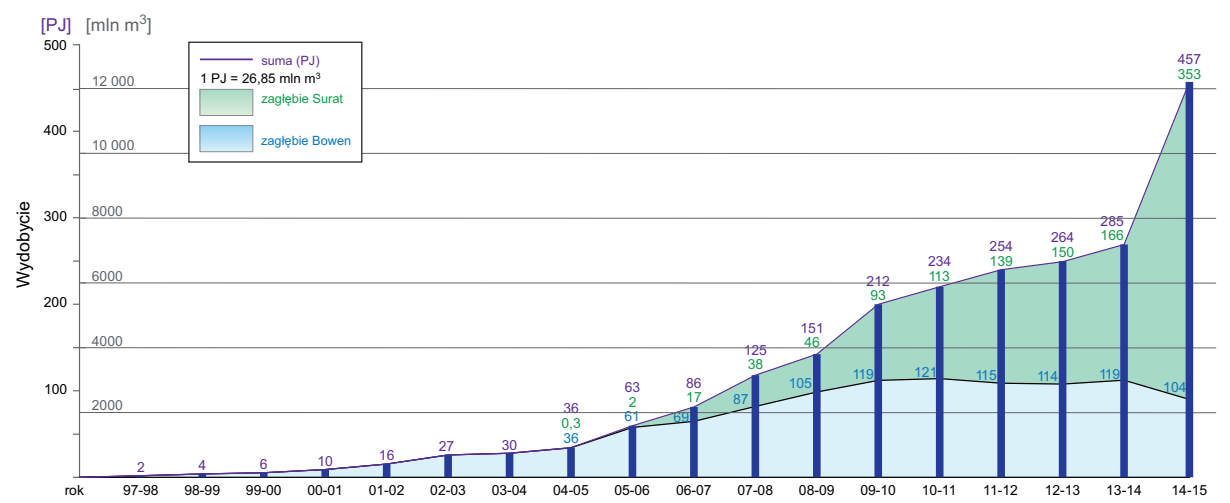

Rys. 3. Wydobycie metanu z pokładów węgla w Australii w latach 1997-2015 [4, poprawione]

\section{Warunki występowania metanu w pokładach węgla}

Gaz ziemny w pokładach węgla występuje głównie w postaci zaadsorbowanej, dlatego o jakości złóż decyduje zdolność sorpcyjna węgli. W składzie gazu dominuje metan, którego udział waha się w granicach od 90\% do 99\%. Zdolność sorpcyjna zbiornika CBM zależy od wielu parametrów: warunków termodynamicznych zalegania pokładu, wilgotności, składu petrograficznego węgli i składu adsorbowanego gazu (domieszki węglowodorów wyższych).

Badania eksperymentalne wykazały, że pojemność sorpcyjna węgli wzrasta wraz ze wzrostem ciśnienia (rysunek 4) i maleje ze wzrostem temperatury.

Generalnie maksymalną zdolność adsorpcji gazu mają węgle bogate $\mathrm{w}$ witrynit $\mathrm{z}$ powodu dominacji mikroporów dodających większą powierzchnię dostępną dla sorpcji, natomiast sorpcja gazu zmniejsza się wraz ze wzrostem zawartości inertynitu [3]. Obserwuje się też dodatnią korelację potencjału sorpcji ze stopniem uwęglenia oraz porowatością węgli. Wzrostowi porowatości towarzyszy często spadek wilgotności. Zawartość substancji mineralnych w węglu wpływa negatywnie na jego pojemność sorpcyjną.

Pokłady węgla najczęściej charakteryzują się dużym zawodnieniem, co utrudnia eksploatację złóż. Jednak woda nasycająca pokłady węgla przeważnie jest wodą słodką lub słabo zmineralizowaną. Umożliwia to wykorzystywanie jej do nawadniania upraw w rolnictwie lub w różnych procesach technologicznych, co sprawia, że jej obecność w złożach nie musi generować kosztów wynikających z konieczności jej utylizacji [20]. Produkcja metanu możliwa jest dopiero po odwodnieniu pokładów węgla. Wypompowanie wody obniża ciśnienie złożowe, co zmniejsza zdolność sorpcyjną pokładu, umożliwiając uwolnienie gazu i jego wydobycie [7].

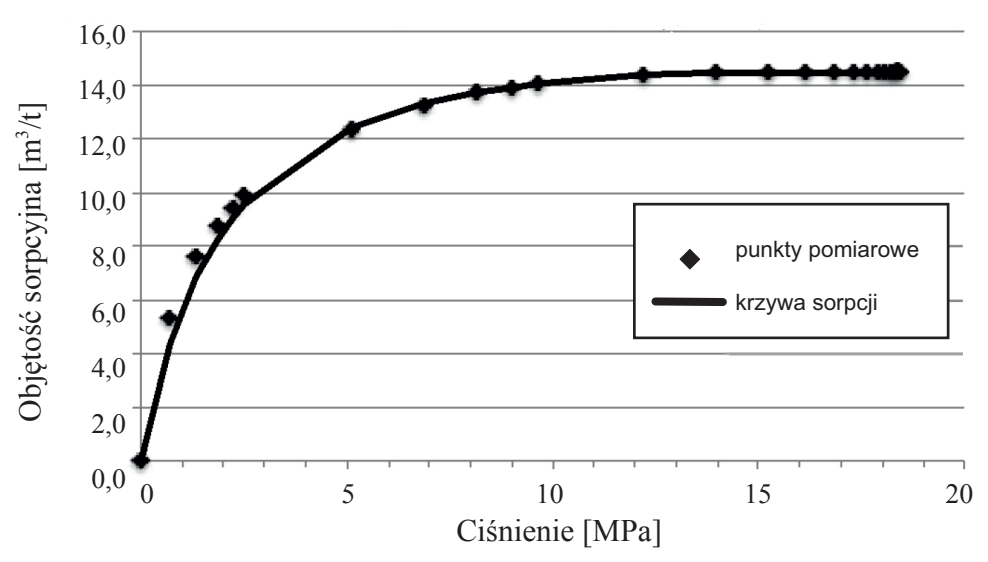

Rys. 4. Zależność objętości adsorbowanego metanu od ciśnienia dla konkretnej próbki węgla, uzyskana w wyniku realizacji prac badawczych w INiG - PIB (Projekt Gasdrain) 

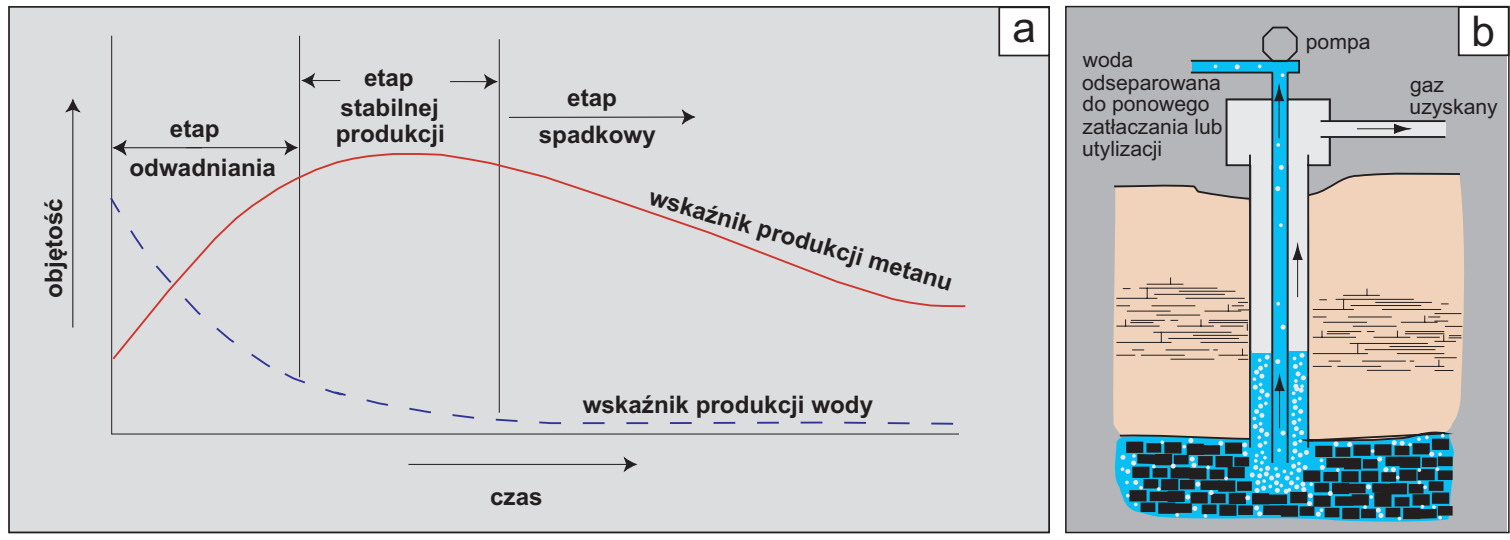

Rys. 5. Typowe krzywe wydobycia metanu i wody z pokładu węgla w czasie - relacja objętościowa (a) [7]. Schemat przedstawiający typowy otwór produkcyjny CBM (b) [11]

W przyszłości produkcja metanu z pokładów węgla może przynieść dodatkowe korzyści, wynikające z możliwości sekwestracji w nich $\mathrm{CO}_{2}$. Wykorzystując właściwości węgla polegające na jego większym powinowactwie chemicznym do $\mathrm{CO}_{2}$ niż do $\mathrm{CH}_{4}$, można zatłaczać przeznaczony do sekwestracji $\mathrm{CO}_{2}$, który będzie wypierał $\mathrm{CH}_{4}$, w efekcie prowadząc do intensyfikacji produkcji metanu oraz pozbycia się niechcianego i szkodliwego dla środowiska $\mathrm{CO}_{2}[2]$.
Należy również mieć świadomość zagrożeń wynikających z eksploatacji CBM. Są nimi szkody górnicze podobne do tych, które powstają przy wydobywaniu węgla w kopalniach podziemnych. Wypompowanie wody i wydobycie metanu obniżają ciśnienie porowe w pokładach węgla, co powoduje wzrost wolnej przestrzeni i efektywnych naprężeń. W konsekwencji prowadzi to do redukcji miąższości pokładu, powodując obniżenie powierzchni terenu i zapadanie gruntu.

\section{Perspektywy produkcji przemysłowej metanu z pokładów węgla niecki GZW}

Wyniki badań prowadzonych w Instytucie Nafty i Gazu Państwowym Instytucie Badawczym [14] wykazują, że potencjał zasobowy GZW jest bardzo duży. W procesie uwęglania substancji organicznej (będącej macierzystą dla pokładów węgla) wygenerowane zostały olbrzymie ilości metanu, w niektórych rejonach niecki przekraczające $20 \mathrm{mld} \mathrm{m}^{3} / \mathrm{km}^{2}$. Wyniki dynamicznego modelowania 4D procesów generowania, migracji i akumulacji węglowodorów wykonanego dla fragmentu GZW wykazują, że sumaryczne ilości metanu zawartego w pokładach węgla zalegających do głębokości $3000 \mathrm{~m}$ mogą przekraczać $500 \mathrm{mln} \mathrm{m}^{3} / \mathrm{km}^{2}$. Zakumulowany metan generalnie nie występuje $\mathrm{w}$ wolnej postaci - ani w poziomach macierzystych (pokładach węgla), ani w poziomach potencjalnych skał zbiornikowych (formacjach utworów klastycznych), lecz w postaci zaadsorbowanej w pokładach węgla, a jego ilości zależą od zdolności sorpcyjnej, która jest definiowana przez parametry Langmuira. Obecność gazu w wolnej postaci nie jest całkowicie wykluczona, ale wyniki przeprowadzonego modelowania wykazują, że możliwości jego występowania są ograniczone. Taki stan rzeczy może wynikać z faktu, że na modelowanym obszarze, zajmującym małą powierzchnię, warstwy zalegają monoklinalnie, brak jest struktur mogących tworzyć pułapki i uskoków stanowiących zamknięcia pułapek. W takim przypadku wygenerowane węglowodory migrują wzdłuż warstw (przepuszczalność lateralna znacznie większa od wertykalnej) i ulegają rozproszeniu poprzez otwarte brzegi modelu. Aby sprawdzić możliwość powstawania złóż konwencjonalnych lub typu tight $\mathrm{w}$ poziomach mułowcowych i piaszczystych, zastosowano możliwą do wykorzystania opcję symulacji przy zamkniętych brzegach modelu. Opcja taka pozoruje występowanie na analizowanym obszarze pułapek z zamknięciami na jego brzegach, a wyniki symulacji przy jej zastosowaniu potwierdzają możliwość występowania akumulacji wolnego metanu zarówno w pokładach węgla, jak i w formacjach klastycznych w postaci złóż niekonwencjonalnych typu tight.

\section{Podsumowanie i wnioski}

Sporządzenie bilansu potencjalnych zasobów metanu w karbońskich utworach niecki GZW oraz wyznaczenie optymalnych stref do poszukiwań może stanowić zachętę dla inwestorów do podjęcia prac prospekcyjnych. Ewentualny suk- ces poszukiwawczy oraz rozpoczęcie eksploatacji mogą zapewnić wielowymiarowe korzyści, takie jak:

- korzyści gospodarczo-ekonomiczne - odbudowa stale pomniejszających się zasobów surowców energetycz- 
nych i poprawa bezpieczeństwa energetycznego poprzez zmniejszenie uzależnienia od importu,

- korzyści bezpieczeństwa pracy - naturalne odgazowanie pokładów węgla kamiennego, przyczyniające się do poprawy bezpieczeństwa pracy górników w kopalniach węgla kamiennego,

- korzyści ekologiczne - zmniejszenie emisji zanieczysz- czeń do atmosfery (energia z gazu wielokrotnie czystsza od energii z węgla), co przy wprowadzeniu kwot emisyjnych $\mathrm{CO}_{2}$ ma również wymiar ekonomiczny,

- korzyści wizerunkowo-propagandowe - wzrost udziału „czystej energii” w ogólnym bilansie energetycznym kraju, poprawiający wizerunek Polski na arenie międzynarodowej.

Prosimy cytować jako: Nafta-Gaz 2017, nr 11, s. 851-856, DOI: 10.18668/NG.2017.11.04

Artykuł nadesłano do Redakcji 16.02.2017 r. Zatwierdzono do druku 2.08.2017 r.

Artykuł powstał na podstawie pracy statutowej pt.: Dynamiczne, przestrzenne (4D) modelowanie karbońskiego systemu naftowego GZW celem oceny potencjatu zasobowego CBM oraz możliwości występowania akumulacji gazu ziemnego typu tight gas w formacjach piaskowcowo-mułowcowych - praca INiG - PIB na zlecenie MNiSW; nr zlecenia: 107/SG, nr archiwalny: DK-4100-97/2016.

\section{Literatura}

[1] Al-Jubori et al.: Coalbed methane - clean energy for the world. Oilfield Review 2009, vol. 21, nr 2, s. 4-13.

[2] Byrer C.W., Guthrie H.D.: Carbon dioxide storage potential in coal beds: a near-term consideration for the fossil energy industry. Proceedings of the $23^{\text {rd }}$ International Conference on Coal Utilization \& Fuel Systems Clearwater, FL, USA, 9-13.03.1998, s. 593-600.

[3] Chattaraj S., Mohanty D., Kumar T., Halder G.: Thermodynamics, kinetics and modeling of sorption behaviour of coalbed methane - A review. Journal of Unconventional Oil and Gas Resources 2016, vol. 16, s. 14-33.

[4] Department of Natural Resources and Mines (Queensland, Australia): Queensland's mining and petroleum industry overview. Lipiec 2016.

[5] Hadro J., Wójcik I.: Metan poktadów węgla: zasoby i eksploatacja. Przeglad Geologiczny 2013, vol. 61, nr 7, s. 404-410.

[6] International Energy Agency: Resources to Reserves 2013. Oil, Gas and Coal Technologies for the Energy Markets of the Future. OECD/IEA, 2013

[7] Kuuskraa V.A., Brandenberg C.F.: Coalbed methane sparks a new energy industry. Oil and Gas Journal 1989, vol. 87, nr 41, s. 49-56.

[8] Kuuskraa V.A., Stevens S.H.: Worldwide gas shales and unconventional gas: a status report. American Clean Skies Foundation (ACSF) and the Research Partnership to Secure Energy for America (RPSEA), 2009.

[9] Li S., Zhang B.: Research of Coalbed Methane Development Well-Type Optimization Method Based on Unit Technical Cost. Sustainability 2016, vol. 8, nr 9, s. 843.

[10] Mastalerz M.: Coal bed methane: reserves, production and future outlook. [W:] T. M. Letcher (ed.): Future energy, second edition. Elsevier 2014, s. 145-158.

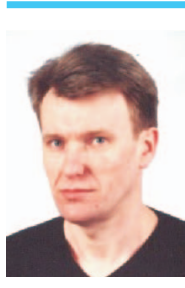

Mgr inż. Tomasz SŁOCZYŃSKI

Główny specjalista inżynieryjno-techniczny

w Zakładzie Geologii i Geochemii.

Instytut Nafty i Gazu - Państwowy Instytut Badawczy

ul. Lubicz 25 A

31-503 Kraków

E-mail: tomasz.sloczynski@inig.pl
[11] Nuccio V.: Coal-bed Methane: Potential and Concerns. U.S. Department of the Interior, United States Geological Survey 2000. Fact Sheet FS-123-00.

[12] Riazi M.R., Gupta R.: Coal Production and Processing Technology. 2016. CRC Press, Taylor \& Francis Group.

[13] Sienkiewicz M., Pytlik A.: Metan z poktadów węgla - stan i perspektywy zagospodarowania surowca na przykładzie polskiej i czeskiej części Górnośląskiego Zagłębia Węglowego. Wiadomości Naftowe i Gazownicze, listopad 2013.

[14] Słoczyński T., Drozd A., Sowiżdżał K.: Ocena potencjału zasobowego CBM (Coal Bed Methane) oraz możliwości występowania akumulacji gazu ziemnego typu tight w formacjach piaskowcowo-mułowcowych GZW. Nafta-Gaz 2017, nr 10, s. 739-749, DOI: 10.18668/NG.2017.10.03

[15] Thomas L.: Coal Geology. Second ed., Wiley-Blackwell, Oxford, UK, 2013.

[16] United States Environmental Protection Agency: Coal Mine Methane Country Profiles. Rozdział 16, czerwiec 2015.

[17] United States Environmental Protection Agency: Coal Mine Methane Country Profiles. Rozdział 6, czerwiec 2015.

[18] U.S. Coalbed Methane production. Strona internetowa U.S Energy Information Administration; http://eia.gov/dnav/ng/ hist/rngr52nus_1a.htm (dostęp: grudzień 2016).

[19] U.S. Coalbed Methane proved reserves. Strona internetowa U.S. Energy Information Administration; http://eia.gov/dnav/ ng/hist/rngr51nus_1a.htm (dostęp: grudzień 2016).

[20] Veil J.A., Puder M., Elcock D., Redweik R.Jr.: A White Paper Describing Produced Water from Production of Crude Oil, Natural Gas, and Coal Bed Methane. Prepared by Argonne National Laboratory, Argonne, Illinois for the U.S. Department of Energy, National Energy Technology Laboratory, USA, 2004.

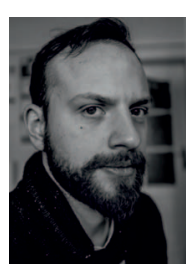

Mgr inż. Arkadiusz DROZD

Specjalista inżynieryjno-techniczny w Zakładzie Geologii i Geochemii.

Instytut Nafty i Gazu - Państwowy Instytut Badawczy ul. Lubicz 25 A

31-503 Kraków

E-mail: arkadiusz.drozd@inig.pl 